\title{
Government Size and Corruption: A Non-linear Analysis in the Case of EMCCA
}

\author{
Assoumou Ondo ${ }^{1} \&$ Beau Jency Owono Ondo ${ }^{2}$ \\ ${ }^{1}$ Maître de Conférences, Agrégé des Sciences Economiques et de Gestion, Chercheur au CIREGED - Omar Bongo \\ University, Gabon \\ ${ }^{2}$ Doctorant, Chercheur au CIREGED - Omar Bongo University, Gabon \\ Correspondence: Assoumou Ondo, Maître de Conférences, Agrégé des Sciences Economiques et de Gestion, \\ Chercheur au CIREGED - Omar Bongo University, Gabon. E-mail: assoumou7ondo@gmail.com
}

Received: June 23, 2020

Accepted: August 7, 2020

Online Published: July 19, 2021

doi:10.5430/rwe.v12n4p17

URL: https://doi.org/10.5430/rwe.v12n4p17

\begin{abstract}
This article analyzes the relationship between Government size and corruption. Unlike the works in the way which suppose a linear relationship between the two variables, we estimate a panel with change of the modes to characterize the impact of the size of the Central Government on corruption, in the countries of the economic community and monetary of Central Africa (EMCCA). The results show that there is a non-linear relationship between these two variables. Indeed, a strong involvement of the Government in economic activity results in a significant increase in corruption when the Government exceeds a size of $13.5508 \%$ of the GDP.
\end{abstract}

Keywords: size of government, corruption, non-linear panel

Classification JEL: H11; D72; E40

\section{Introduction}

The increase in the size of the Government, often justified by its objective of maximizing social well-being (Barro, 1989; Armey, 1995; Rahn et al., 1996 and Scully, 1994, Davies, 2009, Martins and Veiga, 2013) through its functions of stabilization, allocation and distribution (Musgrave, 1959), finds a new explanation in the opportunistic behavior of the public decision-maker (Wittman, 1989 and 1995; Mitchell, 1989; Buchanan, 1954; Tullock, 1965). This new direction has given renewed interest in studying the relationships between Government size and corruption.

The theoretical literature on the interactions between Government size and corruption reveals a two-way relationship between the two variables. The first orientation, initiated by Rose-Ackermann (1978 and 1999) studies the effect of Government size on corruption. She argues that an excessive size of the Government increases the administrative burden and the discretionary power of public decision-makers, thus encouraging more corruption (Leff, 1964; Leys, 1965; Huntington, 1968). The second approach, developed by Mauro (1998); Tanzi and Davoodi (1997), then Liu and Mikesell (2014) are interested in the effect of corruption on the size of the Government. She suggests that the selfishness and opportunism of public decision-makers can encourage them to increase the size of the Government to maximize their personal gains. Thus, the greater involvement of the Government in the economy is explained by the opportunistic behavior of bureaucrats and politicians who only seek to create rents and obtain contributions (McChensey, 1987; Shleifer and Vishny, 1993).

On the empirical level, several works attempt to characterize the effects of the size of the Government on Corruption. Arvate et al. (2010) study the effects of Government size on corruption in the context of the OECD countries and those of Latin America, over the period 1996-2003. They show that the size of the Government causes corruption in both samples. Goel and Nelson (1998), on the other hand, are interested in the specific case of the United States and find that the size of the Government, measured by government spending, positively affects corruption. The authors Holcombe and Bourdeaux (2015) analyze the relationships between the two (2) variables in a sample of 147 countries, including Uganda. They show that the size of the Government, captured through regulation, encourages corruption because it allows civil servants to be paid for contracts with the Government, for subsidies and regulatory favors.

This view is supported by Brollo et al. (2013) by studying the effect of government revenue, a measure of the size of 
the Government, on corruption in Brazil. The results show that a $10 \%$ increase in federal transfers increases corruption by $12 \%$. Contrary to the results of the first studies, which show a positive influence of the size of the Government on corruption, Goel and Nelson (2008) find that a size of the Government, measured by public consumption in gross domestic product (GDP), leads to a decrease in corruption. According to the authors, such a conclusion reflects greater public vigilance against such behaviors or stronger institutions that serve to combat such activities. Subsequently, Kotera et al. (2012), using transnational data from 82 countries over the period 1995-2008, show that an increase in the size of the Government reduces corruption if the level of democracy is high and, on the other hand, can lead to an increase in corruption if democracy is weak.

However, despite this large volume of empirical work in developing countries (Africa: Burkina-Faso, Uganda, Morocco; Latin America: Argentina and Brazil), to our knowledge, there are no studies dealing with relationships between the size of the Government on corruption in the countries of the Economic and Monetary Community of Central Africa (EMCCA). However, the study of the effects of the size of the Government on corruption arises acutely in such a framework for at least two (2) reasons:

$1^{\circ}$ ) First, according to the NGOs Transparency International (TI report, 2018) and the Freedom House, the EMCCA countries are characterized by relatively low values of the corruption perception index (CPI), which places them overall in the "endemic corruption zone", and by high values of the global index of civil liberty (IGLC), characteristic of a Government where the citizens live in fear and repression;

$2^{\circ}$ ) Secondly, the public administrations of the EMCCA countries are, for the most part, characterized by heaviness and excessive regulation. What increases informality slows down the creation and development of businesses (World Bank, 2004 and 2006);

There are a number of studies attempting to explain corruption in EMCCA countries. Indeed, Avom and Gandjon Fankem (2014), analyze the impact of corruption and the quality of the legal framework on international trade, show that a high level of corruption in a country of the union reduces its intra-community trade than its inter-community trade. More recently, Assoumou Ondo (2017) studies the effects of corruption on economic growth. It shows that over the period 2005-2015, corruption has, to a lesser extent, favored economic growth in the EMCCA countries, characterized by excessive administrative heaviness which hamper access to basic public services (water, electricity, education). A result supported by those of Gandjon Fankem (2017) and Loubelo (2018). However, two criticisms can be made of the studies carried out in EMCCA: (i) they are not interested in the causes, but only in the consequences of corruption in the union; (ii) they suggest a linear relationship between the two variables.

Apart from the effects exerted on Economic Growth, via the investment channel, corruption must be considered as a rational response by economic agents (Government, companies and citizens) in a context characterized by excessive red tape, low quality of the institutional framework, an opacity and a concentration of powers in the functioning of the Government, wages below the efficiency salary, etc. In addition, taking into account the size of the Government requires integrating into the analysis of threshold effects, to characterize the changes that are taking place in the behavior of politicians and bureaucrats, as the number of employees, budgets, Government regulations are increasing. These threshold effects suggest that the relationships between corruption and the size of the Government be expressed in a non-linear relationship.

This reflection is therefore a contribution to the analysis of the relationships between the size of the Government and the corruption of the member countries of the EMCCA zone, in that it endogenizes corruption and integrates a threshold effect through the estimation of a static regime change panel with sudden transition. This representation has the double advantage of determining a threshold size of the Government, while capturing possible asymmetric behavior between the two variables in the EMCCA countries. The rest of the study is organized as follows: section 2 presents a review of the literature, section 3 describes the model for determining the threshold effects of Government size on corruption. Section 4 provides an empirical analysis. Finally section 5 concludes.

\section{The Literature Review}

Discussions about the influence of Government size on corruption crystallize around two main approaches. The first considers that a large Government provides more rent-seeking opportunities for politicians and bureaucrats; which translates into more corruption. The second suggests that, since a larger Government strengthens accountability, an increase in the size of the Government should reduce corruption.

\subsection{The Size of the Government, a Source of Corruption}

Rose-Ackerman (1978) argues that regulation is very often associated with the discretionary powers of agents. Indeed, regulations, by design, assign powers to those who must implement them. As a result, more corruption can be 
expected in regulated and controlled economies as opposed to market economies. By extension, the level of corruption is expected to decrease as regulated economies become more liberal. Another empirical study examines the effect of Government size on the corrupt practices of public officials in the United States. Indeed, Goel and Nelson (1998), inspired by Becker's (1968) "crime and punishment" model, use annual data on Governments for the period 1983-1987. They analyze panel and cross-sectional data and show that the size of the Government, especially Government spending, does have a strong positive influence on corruption. The study argues that it is reasonable to expect more rascality with larger Governments. And that a larger Government could also imply greater bureaucratic backwardness by inducing rent-seekers to offer larger bribes.

Likewise, Rose-Ackerman (1999) argues that eliminating spending and regulatory programs can be a powerful strategy for reducing corruption. This result is also supported by Tanzi (2000) who argues that the growth of corruption is probably and closely linked to the growth of certain Government activities. He concludes that corruption will be reduced mainly in countries where Governments are willing to significantly reduce some of their functions.

Holcombe and Boudreaux (2015) use a data set from 147 countries and perform consecutive regressions to examine the relationship between Government size and corruption. They show that increased regulation naturally encourages corruption, as it allows civil servants to be paid for regulatory favors, subsidies and Government contracts. In addition, the authors also show that some countries have relatively large Governments but lower levels of corruption like the Scandinavian countries. Holcombe and Boudreaux (2015) conclude that while institutional differences may explain some of the country differences in corruption, the most consistent relationship is that high levels of regulation are associated with more corruption. Indeed, when examining the effect of Government size, it is the regulatory Government, rather than the productive and distributive Government, that is associated with corruption. In other words, higher levels of government spending are associated with less corruption, and more regulation is associated with more corruption.

Chen and Qijun (2018) study the relationship between public sector wages and corruption in China. Corruption is measured by the value of bribes obtained by government officials as reported in court proceedings. Data cover the period 1985-2014. The authors hypothesize that public sector wages are a benchmark for bribe payers and bribe takers in determining the value of bribes, and that the possibility of external wages for comparison with public sector wages, as proposed by the fair wage hypothesis is not required to determine the relationship between public sector wages and corruption. The empirical results confirm their hypothesis. Furthermore, they find no consistent support for the fair wage hypothesis but a systematic U-shaped relationship between public sector wages and corruption. The authors conclude that higher public sector "carrots" reduce corruption when public sector wages are low, but when public sector wages are high, "sticks" rather than carrots seem necessary to deter corruption.

Yamshchiko et al. (2018) analyze the relationships between employment and the perception of corruption in the public sector for 72 countries around the world. The authors show that, despite the common notion, countries with "smaller" governments do not tend to have lower corruption. According to general hypotheses, it can be demonstrated that there is an "optimal size" of public sector employment corresponding to the highest capital intensity. The model has several implications: optimal optimal sizes of government for labor-intensive countries and larger sizes for capital-intensive countries; the possibility of reducing corruption by paying a suboptimal cost of production and a higher "price" of oversized government for labor-intensive countries.

Studies showing the effects of Government size on corruption have shown mixed results. Certainly, several studies have a positive and significant relationship between the two variables, the fact remains that an opposite relationship can be observed.

\subsection{The Size of the Government, an Obstacle to Corruption}

Using cross-national data from around 100 countries, Goel and Nelson (2008) show that larger government sizes lead to lower corruption. The authors show that a large public sector, measured by the share of public consumption in GDP (size of government), does not in itself contribute to the perceived level of corruption in a country. In fact, they find exactly the opposite effect: greater public sector presence is associated with less corruption, which may reflect greater public vigilance against such behavior or stronger institutions that serve to combat such activities. However, it is also clear that certain forms of Government intervention, in particular regulatory intervention, encourage corruption by creating greater possibilities for accepting bribes and engaging in corrupt behavior.

Following this, a study by Billger and Goel (2009) attempts to explain the determinants of corruption activities using data from a representative sample of countries and applies two regressions by Ordinary Least Squares and by 
quantile. They challenge the idea that eliminating regulations and promoting free trade will uniformly reduce corruption. According to this study, greater economic freedom, while important, is not statistically significant. This suggests that dismantling the restrictions does not reduce corruption as much.

Parungao Magtulis and Poquiz (2016) examine the relationships between the size of government and corruption in the Philippines. They analyze public spending and its relationship to the persistent political problem of public corruption. The authors find that, contrary to expectations, larger disbursements actually improve the public's perception of bureaucratic corruption, similar to the effect of improved institutions and the rule of law.

It appears that the current literature on the relationships between Government size and corruption does not take into account the behavioral changes taking place in public administration as the size of the Government changes. Indeed, a size of the Government, beyond a certain threshold, can generate more or less opportunistic behavior and therefore influence the level of corruption. In addition, the existence of non-linear effects of Government size (Barro, 1989; Armey, 1995; Rahn et al., 1996 and Scully, 1994) and corruption (Ventelou, 2002; Mauro, 2004; Swaleheen, 2011; Mallik and Saha, 2016) on Gross Domestic Product also suggests a non-linear relationship between the two variables. Furthermore, it should be noted that the studies interested in the non-linearity of the relationships between the size of the Government have considered a U-inverted relationship between the two variables (Yamshchiko et al., 2018; Chen and Qijun, 2018), which suggests a symmetry of behavior before and after the threshold.

Thus, our analysis differs from the existing literature in that it determines the non-linear effects of the size of government on the level of corruption, while postulating an asymmetry of behavior beyond a certain dimension of the Government.

\section{The Model for Determining the Asymmetric Effects of the Size of Government on Corruption}

Many avenues are explored to model the non-linearity between variables. The path that has proven to be the most successful, however, is that of regime-change models, which have the advantage of providing an economic explanation of non-linearity (Hansen, 1999; Gonzalez et al., 2005). These types of model allow an economic series to have a different dynamic depending on the regimes in which it finds itself (Tong, 1978 and Tong \& Lim, 1980). The difficulty of regime change models rests mainly on the identification of the variable defining the regime, on the one hand, and the transition mechanism, on the other. In fact, two transition mechanisms are possible and depend on the form of the transition function used: smooth or brutal. In this study, we will focus on the brutal transition mechanism which takes the form of an indicator function. Thus, the transition from one regime to another can be done in a period and it is done by comparing the transition variable to an estimated threshold.

The Brute Transition Regime Panel (PTR) that we use has the double advantage of providing an economic explanation of non-linearity and authorizing an economic series to have a different dynamic depending on the regime in which it is found. It also makes it possible to question the stability of the coefficients over time. However, unlike the rupture models, the transition from one regime to another is neither dated nor final, being determined according to the threshold.

Our model suggests that the relationship between corruption and the size of the Government depends on the threshold level of Government size; the effects being asymmetrical on either side of the threshold to be determined. We assume that the change of regimes influence the effects of the size of the government (size) on corruption (corr).

The relationship between corruption and the size of the government is as follows:

$$
\text { Corr }_{\mathrm{it}}=\left(\mathrm{b}_{1} \text { size }_{\mathrm{it}}\right) * \mathrm{I}\left(\text { size }_{\mathrm{it}} \leq \gamma\right)+\left(\mathrm{b}_{2} \text { size }_{\mathrm{it}}\right) * \mathrm{I}\left(\text { size }_{\mathrm{it}} \leq \gamma\right)+\theta_{0 \mathrm{i}}+\mathrm{a}_{\mathrm{i}} \mathrm{X}_{\mathrm{it}}+\varepsilon_{\mathrm{it}}
$$

And for $\mathrm{i}=1,2, \ldots, \mathrm{n}$ and $\mathrm{t}=1,2, \ldots, \mathrm{T}$

With:

- Size, The size of the government, and also the variable threshold;

- $\quad X_{\mathrm{it}}$, combines the previously selected control variables;

- $\quad \gamma$, is the threshold;

- $\quad a_{i}$, the coefficients of control variables not influenced by the plans;

- $\quad \theta_{0 \mathrm{i}}$, represents the fixed effect;

- $\quad b_{i}$, and are marginal effects, respectively in diets 1 and 2;

- I, an indicator function which takes the value 1 if the condition is met brackets and 0 otherwise;

- $\varepsilon$, the error term. 
Like Chaudhry, Anwar et al. (2007), the control variables used are economic and not economic. With regard to economic variables, we consider that government employees seek to maximize their purchasing power (Rijckeghem and Weder, 1997). We consider that this purchasing power is influenced by the ease of access to credit and the inflation rate (Elkamel, 2019). For non-economic variables, we have identified the level of democracy (Johnston, 2000) and the quality of regulatory institutions (La Porta et al., 1999; Avom and Gandjon, 2014). Determining the $\gamma$ threshold is a prerequisite for estimating marginal effects. The value of the threshold $\gamma$ is determined so as to minimize the sum of the squares of the residuals (SSR).

It will be possible, after estimating models to determine the asymmetric effects on the size of the government of corruption in the EMCCA member countries.

\section{Empirical Analysis}

The data used to estimate our models cover the period 2005-2017 (13 years for the six EMCCA countries. This corresponds to 78 observations). The series selected come from different secondary sources. This is the corruption perception index (corr) calculated by Transparency International (TI). The Democracy Index created in 2006 by the Economist Group (demo). The other indicators, such as credit to the private sector (cdsp), the inflation rate (inf), the quality of regulatory institutions (qinst) and government final consumption expenditure (size), are extracted from the base World Bank data (WDI, 2017).

The estimation of the model [1] is performed by the econometrics of panel data. This formulation has the double advantage of enlarging our sample, and also of taking into account the individual specificities of EMCCA member countries. The threshold size of the Government and its asymmetrical effects are determined by estimating the regime change with abrupt transition (PTR) model according to the method of Hansen (1999).

The results of the Fischer heterogeneity tests show that the BEAC countries are heterogeneous, thus confirming the possibility of estimating the model in the form of a panel (prob> $F=0.000$ ). In addition, Hausman's (1978) test supports the idea that the most relevant model for estimating the relationship between corruption and Government size has a fixed effect (prob> khi2 $=0.0030$ ). All the results of these tests are available on request.

The estimate of the single threshold by the bootstrap method is provided by the table below:

Table 1. Threshold effect test

\begin{tabular}{lcrrr}
\hline Tests (bootstrap = 300) & threshold & Minimal & Maximal & \multicolumn{1}{c}{ p-value } \\
\hline Single & $13.5508^{*}$ & 12.9587 & 13.6741 & 0.0120 \\
\hline
\end{tabular}

Note: The determinants of growth are represented here. Student's tests on each coefficient are based on a null hypothesis of significance at zero and an alternative hypothesis of non-significance at zero. When the coefficient is preceded by $(*)$ then the null hypothesis is rejected at the $1 \%$ threshold; for $(* *)$ the null hypothesis is rejected at the $5 \%$ threshold; for $(* * *)$ it is rejected at the $10 \%$ threshold.

The significance of the single threshold confirms the non-linearity of the relationship between Government size and corruption. Thus, the transition from regime 1 (small Government size) to regime 2 (large Government size) takes place when the size of the Governments of the EMCCA countries rises above $13.5508 \%$ of the GDP. The 95\% confidence interval for this threshold is between 12.9587 and 13.6741.

The robust estimation of the model leads to the results presented in the table below. 
Table 2. Model estimation

Endogenous Variable: Corruption ( corr $^{\left.\text {corr }_{i, t}\right)}$

\begin{tabular}{lcc}
\hline Exogenous variables & \multicolumn{2}{c}{ Coefficients } \\
\cline { 2 - 3 } & Regime 1 & Regime 2 \\
\hline Size of Government (size) & 0.00507 & $-0.67039^{* *}$ \\
Democratie (demo) & 0.03547 & $3.7783^{* *}$ \\
Credit to the private sector (cdsp) & 0.1003 & 0.1003 \\
Inflation Rate (inf) & -0.02363 & -0.02363 \\
Quality of institutions (qinst) & $-4.7572^{* * *}$ & -4.7572 \\
Constant & 27.7202 & 27.7202
\end{tabular}

Note: Represented here determinants of growth. Student tests on each coefficient based on a null hypothesis significance to zero and alternative hypothesis of no significance to zero. When the coefficient is preceded by $(*)$, then the null hypothesis is rejected at the $1 \%$; for $(* *)$ the null hypothesis is rejected at the $5 \%$ level; for $(* * *)$ is rejected at the $10 \%$ threshold.

The overall significance of the estimated model (prob> $F=0.0350$ ) and that of the $5 \%$ threshold confirm the relevance of the nonlinear relationship to two regimes used.

\section{Discussion}

The results of Tables 1 and 2 confirm the existence of a non-linear relationship between the size of the Government and Corruption in the EMCCA countries. In fact, the threshold is identified after estimation of the regime change panel is fixed at $13.5508 \%$ of the GDP. This threshold makes it possible to reconcile the studies of Avarte et al. (2010), then Chen and Liu (2018) with those of Goel and Nelson (2008), Kotera et al. (2012), while taking into account the role played by democracy and the quality of regulatory institutions. Indeed, when the size of the government is below the threshold of $13.55 \%$ of GDP (regime 1), it has no significant impact on the perception of corruption in the sub-region. Furthermore, even if it is not significant, the positive sign of the coefficient shows that a small government size could curb opportunistic behavior, which does not encourage the use of corrupt activities. However, when the size of the Government rises above $13.5508 \%$ of GDP (regime 2), the increase in the size of the Government has a negative and significant effect on the corruption perception index (- 0.67039), corresponding to an increase in the level of perceived corruption. The increase in the size of the Government beyond $13.55 \%$ of the GDP reduces transparency and vigilance in public administration, which erodes the efforts made in terms of the fight against corruption. In this context, democracy (demo) and the quality of regulatory institutions (qinst) reduce corruption (by $3.7783 \%$ and $4.7572 \%$ respectively). Thus, beyond $13.5508 \%$ of GDP, bribes and greasing of legs become essential to benefit from certain public services, even the most basic (access to electricity, water, schools and public sector hospitals, etc.).

\section{Conclusion}

In this article we have studied the relationship between Government size and corruption in EMCCA member countries from a panel of regime change with brutal transition (PTR). After estimating the impact of Government size on corruption, we determined a threshold beyond which the size of government has asymmetric negative effects on the Corruption Perceptions Index. More specifically, the results highlight an asymmetric relationship between the two variables. Indeed, Government intervention increases corruption when its size exceeds a threshold of $13.5508 \%$ of GDP.

\subsection{Implications}

This result shows that the governments of EMCCA countries should intervene less in economic activity, in order to guarantee a government size below $13.550 \%$ of GDP. Indeed, beyond this threshold, central government surveillance, control and incentives of bureaucrats become difficult, if not impossible. This freedom of action, combined with opportunistic behavior by bureaucrats, encourages corrupt behavior. This increase in corruption, due to the growing size of government and red tape, is likely to impact investment spending, economic growth, pollution, social inequalities, etc. 


\subsection{Limitations and Future Directions}

Although the results of our study are promising for organizations fighting against corruption in the public sector, our analysis would benefit from integrating other dimensions of the size of the State, such as the wage bill, intensity of regulation and taxation. In addition, corruption is captured globally, through the corruption perception index. We believe it is appropriate to take into account the different dimensions of corruption, namely: the distinction between top and bottom corruption, on the one hand, and the difference between active and passive corruption, on the other. However, such data is not available in EMCCA countries. By always focusing on the problem of corruption in the economies of the EMCCA zone, we intend, in future work, to orient ourselves towards the study of the relations between corruption and pollution and, then, between Corruption and banking performance.

\section{Acknowledgements}

First of all, we would like to thank the editor and the referee for their comments. Our thanks also go to the various members of the International Center for Reflexion in Economics and Management for Development (CIREGED) for the day-to-day discussions. Nonetheless, I am solely responsible for any errors and omissions in this study.

\section{References}

Arellano, \& Bond, S. (1991). Some tests of specification for panel data: Monte Carlo Evidence and an Application to Employment Equations. Review of Economics Studies, 58, 277-297. https://doi.org/10.2307/2297968

Armey, D. (1995). The Freedom Revolution. Washington, Regnery Publishing.

Barro, R. (1989). A Cross-Country Study of Growth, Saving and Government. NBER Working Paper No. 2855. Mimeo. https://doi.org/10.3386/w2855

Buchanan, J. M. (1954). Individual Choice in Voting and Market. Journal of Political Economy, 62(3), 334-43. https://doi.org/10.1086/257538

Chen, Y., \& Liu, Q. (2018). Public-sector wages and corruption: an empirical study. European Journal of Political Economy, 54(C), 189-197. https://doi.org/10.1016/j.ejpoleco.2018.06.006

Davies, A. (2009). Human development and the optimal size of government. The Journal of Socioeconomics, 38 , 326-330. https://doi.org/10.1016/j.socec.2008.07.015

Goel, \& Nelson, M. (1998). Corruption and Government size: a Disaggregated Analysis. Public Choice, 97(1-2), 107-20. https://doi.org/10.1023/A:1004900603583

Goel, \& Nelson, M. (2008). Cause of Corruption: history, geography and government. BOFIT Discussion Papers 6/2008. https://doi.org/10.2139/ssrn.1141772

Hansen. (1999). Threshold effects in non-dynamic panels: Estimation, testing and inference. J. Econom. 93(2), 345-368. https://doi.org/10.1016/S0304-4076(99)00025-1

Hausman, J. A. (1978). Specification tests in econometrics. Econometrica, 46(6), 1251-1271. https://doi.org/10.2307/1913827

Holcombe, R., \& Bourdeaux, C. (2015, July). Regulation and corruption. Public Choice, 164(1-2), 75-85. https://doi.org/10.1007/s11127-015-0263-x

Huntington, S. (1968). Political Order in Changing Societies. Yale University Press, New Haven, Connecticut.

Leff. (1964). Economic Development through Bureaucratic Corruption. The American Behavioral Scientist, 8, 8-14. https://doi.org/10.1177/000276426400800303

Leys, C. (1965). What Is the Problem about corruption?. Journal of Modern African Studies, 3, 215-230. https://doi.org/10.1017/S0022278X00023636

Liu, C., \& Mikesell, J. L. (2014). The Impact of Public Officials' Corruption on the size and allocation of US Government Spending. Public Administration Review, 74(3). https://doi.org/10.1111/puar.12212

Martins, S., \& Veiga, F. J. (2013). Government size, comporition of public expenditure, and economic development, Documentos de Trabalho. Working Paper Series, WP NIPE 17/2013.

Mauro, P. (1998). Corruption and the Composition of Government Expenditure. Journal of Public Economics, 69, 263-279. https://doi.org/10.1016/S0047-2727(98)00025-5

Mauro, P. (2004). The Persistence of Corruption and Slow Economic Growth. IMF Staff Papers, 5, 1-18. Not quoted in the document. 
McChensey, F. S. (1987). Rent and Rent Extraction Creation in the Theory of Regulation Economics. Journal of Legal Studies, 16(1), 101-18. https://doi.org/10.1086/467825

Mitchell, W. C. (1989). Chicago Political Economy: A Public Choice Perspective. Public Choice, 63, 282-292. https://doi.org/10.1007/BF00138168

Rahn, R., \& Fox, H. (1996). What is the Optimum Size of Government. Vernon K. Kriebe Foundation.

Rose-Ackerman. (1978). Corruption: A Study in Political Economy. New York: Academic Press. https://doi.org/10.1016/B978-0-12-596350-3.50005-3

Rose-Ackerman. (1999). Corruption and Government: Causes, Consequences, and Reform. Cambridge University Press. https://doi.org/10.1017/CBO9781139175098

Scully, G. (1994). What is the Optimal Size of Government?. Policy Report, No. 188, National Center for Policy Analysis, Dallas.

Shleifer, A, \& Vishny, R. W. (1993). Corruption. Quarterly Journal of Economics, 108, 599-617. https://doi.org/10.2307/2118402

Tanzi, V., \& Davoodi, H. (1997). Corruption, Public Investment, and Growth. IMF (International Monetary Fund) Working Paper 139, 1-23. https://doi.org/10.5089/9781451929515.001

Tullock. (1967). Welfare Costs of Tariffs, Monopolies and Theft. Western Economic Journal, 5, 224-232. https://doi.org/10.1111/j.1465-7295.1967.tb01923.x

Wittman, D. (1995). The Myth of Democratic Failure: Why Political Institutions Are Efficient. Chicago: University of Chicago Press.

\section{Copyrights}

Copyright for this article is retained by the author(s), with first publication rights granted to the journal.

This is an open-access article distributed under the terms and conditions of the Creative Commons Attribution license (http://creativecommons.org/licenses/by/4.0/). 